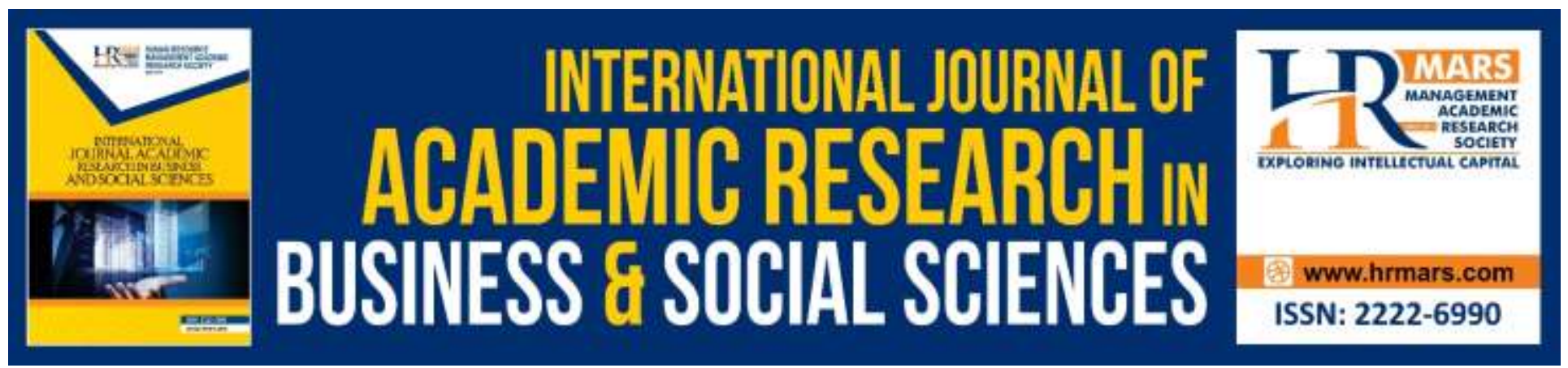

\title{
Post-Conflict Peace-Building and the Way Forward: The Impact of Insurgency of Boko Haram on the People of Yobe State, Nigeria
}

Abdullahi Umar, Adam Andani Mohammed \& Md. Sayed Uddin

To Link this Article: http://dx.doi.org/10.6007/IJARBSS/v9-i6/5953 DOI: $10.6007 /$ IJARBSS/v9-i6/5953

Received: 11 April 2019, Revised: 18 May 2019, Accepted: 09 June 2019

Published Online: 29 June 2019

In-Text Citation: (Umar, Mohammed, \& Uddin, 2019)

To Cite this Article: Umar, A., Mohammed, A. A., \& Sayed Uddin, M. (2019). Post-Conflict Peace-Building and the Way Forward: The Impact of Insurgency of Boko Haram on the People of Yobe State, Nigeria. International Journal of Academic Research in Business and Social Sciences, 9(6), 393-406.

\section{Copyright: (C) 2019 The Author(s)}

Published by Human Resource Management Academic Research Society (www.hrmars.com)

This article is published under the Creative Commons Attribution (CC BY 4.0) license. Anyone may reproduce, distribute, translate and create derivative works of this article (for both commercial and non-commercial purposes), subject to full attribution to the original publication and authors. The full terms of this license may be seen at: http://creativecommons.org/licences/by/4.0/legalcode

Vol. 9, No. 6, 2019, Pg. 393 - 406

Full Terms \& Conditions of access and use can be found at http://hrmars.com/index.php/pages/detail/publication-ethics 


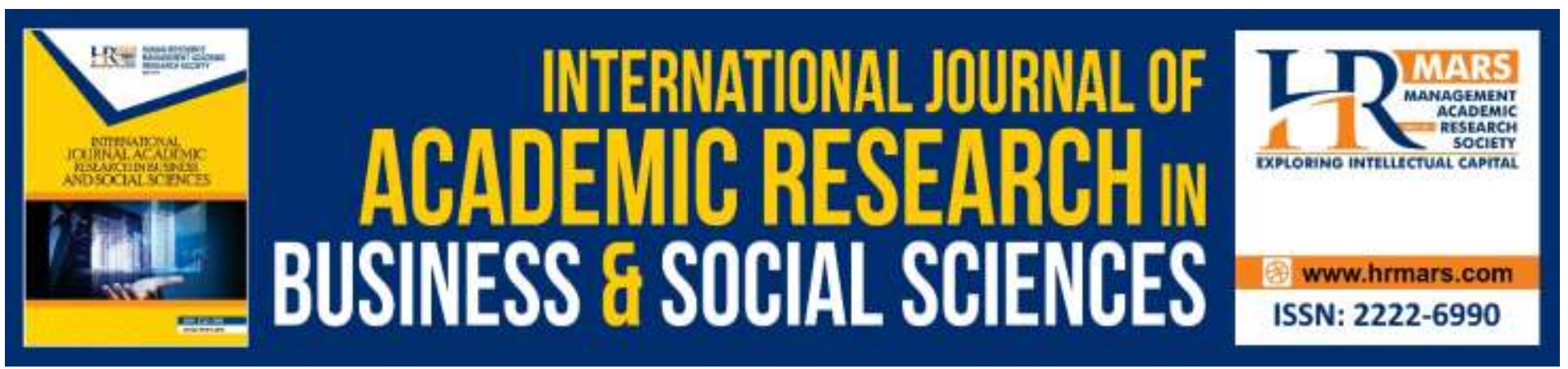

\title{
Post-Conflict Peace-Building and the Way Forward: The Impact of Insurgency of Boko Haram on the People of Yobe State, Nigeria
}

\author{
Abdullahi Umar \\ Department of Sociology and Anthropology, University of Maiduguri, Borno State, Nigeria \\ Adam Andani Mohammed \\ Social Work Studies, Faculty of Social Sciences and Humanities, Universiti Malaysia Sarawak, \\ Sarawak, Malaysia.
}

\section{Md. Sayed Uddin}

Sociology and Social Anthropology, Faculty of Humanities, Arts and Heritage, Universiti Malaysia

Sabah (UMS), Kota Kinabalu, Sabah, Malaysia

Email: abdullahiumar2010@gmail.com,maandani@unimas.my

\begin{abstract}
The paper explores the effect and post conflict peace-building in the Northeastern part of Nigeria with particular reference to Yobe state after the devastating effect of the Boko Haram insurgence. The insurgence engulfed and damaged almost all aspect of the community's life thus includes; destruction of homes schools, hospitals, business premises, police stations, military formations, government offices and other emergency services in various parts of the state. Boko Haram devastations had affected the entire population of Yobe state in every aspects of living ranging from social, economic to political aspects. The study adopted qualitative and critical content analysis through analysis of data on violence inflicted by Boko Haram in Northeastern Nigeria. This study focused on articles available in English and adopted secondary data analysis approach. The reviewed sources include data collected from published textbooks, online search engines, scholarly journals and newspapers in areas of conflict. The data collected through these multiple sources and varied interpretations were analyzed in line with the research objectives. The study revealed that the emergence of Boko Haram can be attributed to political and socio-economic situation of northeastern Nigeria. It also found the victims of Boko haram to include but not limited to children, women, the aged, traditional leaders, religious leaders and their followers, government officials and the
\end{abstract}


INTERNATIONAL JOURNAL OF ACADEMIC RESEARCH IN BUSINESS AND SOCIAL SCIENCES Vol. 9, No. 6, June, 2019, E-ISSN: 2222-6990 @ 2019 HRMARS

security forces. Some recommendations on how to achieve a sustainable peace and peace-building processes have been suggested.

Keywords: Peace-Building, Boko Haram, Corruption, Poverty, Unemployment, Insurgence

\section{Introduction}

There has been a history of communal conflicts and ethnoreligious violence among different communities in Nigeria. The weakness of the political institutions, security and intelligence apparatuses, the failure to define what the national culture and identity is as well as failure to act decisively result in threats to stability (Walker, 2012; Adesoji, 2011; Abdullahi, \& Terhemba, 2014). Saleem (2012) added that the government inability to curb corruption, inequality, human rights abuse and inaccessible education are some concerns. As such some individuals and groups think the only way to deal with the threat and institutional weakness is to resort to violence. Several recent studies attest to the fact that Boko Haram (literally, means 'book is sinful') was created due to circumstances of this nature (Amusan, \& Ejoke, 2017; Walker, 2012; Adesoji, 2011; Uzodike, \& Maiangwa, 2012). As an Islamic sect, Boko Haram accused northern politicians sinful and sacrilegious Western education as a group of corrupt and false Muslims. They therefore waged war against them as well as the Federal Republic of Nigeria with the demand to create Islamic state ruled by sharia (Walker, 2012; Bumah and Adelakun 2009; Adesoji, 2010). Their origin lies in a group of radical Islamist youth who worship in a Mosque in Maiduguri. They declared the city and the Islamic establishment to be irredeemably corrupt. It moved from Maiduguri to Kanama in Yobe state to set up a separatist community run on Islamic principles. From there they started a campaign of assassinations with hit-and-run attacks against police checkpoints and spread riots across Bauchi, Kano, Yobe, and Borno over a five-day period (Amusan, \& Ejoke, 2017; Bakare et al., 2009; Owuamanam et al., 2009; Adesoji, 2011; Matthew, \& Fada, 2014). In recent times, Yobe and other states in northern Nigeria have been experiencing security threats due to the activities of Boko Haram. Eric (2012) stated that it is not only school children who are inconvenienced but others are also affected. It is clear that the socioeconomic activities, movement of people, goods and services are affected by the activities of this group since 2009 (Forest, 2012; Amusan, \& Ejoke, 2017; Abdullahi, \& Terhemba, 2014). As such, the people in the country and Yobe State in particular are worried over the insecurity and are calling for peace and normalcy.

Peace is not only the absence of war but include sustainable satisfaction of individual and collective consumption needs in the society. Two years after President Muhammadu Buhari's administration assumed office a significant military victories and gains have been made against the Boko Haram insurgence in Northern Nigeria. Presently, the Boko Haram group controls a very little territory, compare to territories that use to be under their control. President Muhammadu Buhari, a former general with the Nigerian Army, took a powerful military approach against the Boko Haram militant group. Few weeks after assuming office, he directed the relocation of military command to Maiduguri, with a new operation theatre. President Buhari equally changed all the service chiefs, called for daily monitoring reports, and overhauled the entire counter-insurgency strategy. On the basis that the previous administration had failed to properly equip and support costs for military operations in the northeast. The Buhari's administration pushed a bill for supplementary military spending of USD 187 million (Federal Ministry of Budget and National Planning, 2016). This 
INTERNATIONAL JOURNAL OF ACADEMIC RESEARCH IN BUSINESS AND SOCIAL SCIENCES Vol. 9, No. 6, June, 2019, E-ISSN: 2222-6990 @ 2019 HRMARS

tremendous success recorded war against insurgency made the government to announce publicly on 24 December 2015 that "technically" Nigeria had "won the war against Boko Haram." (BBC, 2015). The essence of this paper is not only the identification of those effects but also to suggest strategies of peace-building and recommend the possible solutions and the way forward. So the paper reviewed concepts such as post conflict peace building, effect of conflict and the way forward.

\section{Materials and Methods}

This narrative study focused on articles available in English and adopted secondary data analysis approach. Data were taken from the internet, books and papers published in areas of religious and ethnic conflict using Google scholar. This study therefore summarized the data collected from these relevant articles that span from 2009 to 2018 and referring to details from earlier studies as indicated in the footnotes. The data collected through multiple sources and varied interpretations were analyzed in line with the research objectives. The analysis of the documents in documentary research was qualitative analysis.

The qualitative method of data analysis is about identifying and understanding the characteristics and traits of the object of inquiry. So the main themes used in the study were derived from the data after several readings and analysis. These themes were generated based on the frequency of appearance in the secondary data and information obtained from the review. The target participants of the study were Boko Haram and its victims through the media reports and scholarly articles which included article references and other articles citing them. The studies included in the review were also based on articles explaining the forms and reasons for conflict particularly Boko Haram insurgency as well as its impact on Yobe society.

The selection of methodology for this study is guided by the three common features of documentary method (Judd et al., 1991). First, the analyses of data for the purposes of particular studies in social relation. Second, the calls for ingenuity in translating existing records into quantifiable indices of some general concepts. Third, the susceptibility to alternative interpretation for the natural events and their effects.

The rationale for this particular method is to proffer newer and broader insights into the ongoing discourse on the Boko Haram insurgence considering its recognition for space and time. Its descriptive nature makes it possible to capture the insights from scholarly exegesis as well as evidence from the historical insurgence of Boko Haram in the country. It also makes it easy for ideas and thoughts to be organized into a number of themes and subthemes for the purpose of effective analysis. It involves systematic method of collecting data from relevant area and necessary information that present a good picture of the phenomenon.

\section{Findings}

Northeastern part of Nigeria is a region that had experienced the devastating effect of the notable terrorist organization the Boko Haram insurgency as from 2009 to 2017. The negative impact of the insurgence identified in this region cannot be overemphasized. Therefore, the following themes were generated and discussed in relation to the effect of Boko Haram activities on Yobe State.

\section{Peace building and Impact of Boko Haram}


Peace-building and peaceful co-existence among warring parties is one of the most tedious and difficult task to achieve in the history of mankind. Experiences had shown that once peace is lost it becomes difficult to rebuild peace and restore normalcy in a short term period. As expressed, peace building is said to be the process of acquiring the values, the knowledge to develop the right attitude, skills and behavior to live in harmony with oneself and with others (Alao, Atere, \& Alao, 2012). For that matter peace-building requires multiple strategies and concerted effort in order to achieve sustainable peace which can guarantee confidence, trust and harmonious co-existence between the warring parties. It is clear that efforts to achieve relative calm or enforce peace forcefully or through persuasion cannot ensure an everlasting peace. Invariably, any effort made to enforce peace through military measures can hardly produce the desired peace, it can only lead to temporary ceasefire or what is termed "a fragile peace". So also fragile peace agreements and peace initiatives are equally bound to fail. As such, the traumas the people are faced with often necessitate the call for conflict peace building not just for those who are directly or indirectly affected by the crisis over time but for prosperity of those states (Terwase, Abdul-Talib, Zengeni, \& Terwase, 2015). Looking back, Francis ${ }^{1}$ stated that peace agreements do not in themselves end wars or bring about lasting peace. In most cases, prewar continuities and the war mentality jeopardizes the prospects of a consolidated peace and postwar reconciliation. Besides, Licklider ${ }^{2}$ assert that only one-third of the negotiated settlements of 'identity civil wars' (or ethnic conflicts) between 1945 and 1993 that lasted for at least five years resulted in lasting peace. Therefore, ending of overt violence via a peace agreement or military victory does not necessarily mean the achievement of peace.

Peace-building is a difficult concept to defined and more challenging to attain its ultimate objective. Peace-building incorporates so many aspects and efforts primarily geared to achieve a durable and sustainable peace. Evans ${ }^{3}$ observed that peace-building is the idea of meeting needs: for security and order, for a reasonable standard of living, and for recognition of identity and worth. In the words of Lambourne ${ }^{4}$ it is a strategy designed to promote a secured and stable lasting peace in which the basic human needs of the population are met and violent conflicts do not recur.

There are certain key important operational concepts that can be found in almost all the aforementioned definitions. These concepts include redressing their grievances, or rehabilitating and restoration of lost hope, restoring their fundamental human dignities, involving all the disputing parties in designing and implementation of the peace process, meeting their basic human needs, engaging them in viable economic activity and ensuring that the conflict did not repeat itself. The process of peace-building calls for new attitudes and practices: ones that are flexible, consultative and collaborative and that operate from a contextual understanding of the root causes of conflict. Once the underlined issues are clearly and categorically addressed the issue of peace building can

\footnotetext{
${ }^{1}$ A paper presented during a security session entitled "Tortuous Path to Peace: The Lome Accord and Postwar Peacebuilding in Sierra Leone” 31:3 (September 2000), p. 357.

${ }^{2}$ Roy Licklider, (1995) “The Consequences of Negotiated Settlements in Civil Wars, 1945-1993", American Political Science Review, 89:3 (September 1995), pp. 685-687.

3 See details in Gareth Evans, (1993) Cooperating for Peace: The Global Agenda for the 1990s and Beyond. (Sydney: Allen \&Unwin, 1993), p. 39.

${ }^{4}$ See Wendy R. Lambourne (2004) "Justice and Reconciliation: Post-Conflict Peace building in Cambodia and Rwanda", PhD Thesis, University of Sydney, 2004.
} 
INTERNATIONAL JOURNAL OF ACADEMIC RESEARCH IN BUSINESS AND SOCIAL SCIENCES

Vol. 9, No. 6, June, 2019, E-ISSN: 2222-6990 @ 2019 HRMARS

successfully be achieved despite the increasing numbers of displaced persons, destruction of property as well as killing and maiming of innocent parents and children leading to psychological destabilization experienced by the state.

\section{Huge number of Internal Displace People}

The country experienced massive internal displacement crisis, especially in the north-eastern part. According to the Internal Displacement Monitoring Centre (IDMC, 2015), there were about 2.2 million people displaced in Nigeria as of end of 2015, most of whom fled Boko Haram violence since 2014 (Eme, Azuakor, \& Mba, 2018). The internal displacement of people leads to increased insecurity, tensions and vulnerabilities among the people in the affected communities. Thus expose them to risks like severe food insecurity and sexual abuse (Alobo, \& Obaji, 2016; Mohammed, 2011; Eme et al., 2018). Studies have shown that the people displaced are sheltered in small and confined spaces which often lead to overcrowding with inadequate physical protection and healthcare, constraints on resources, loss of livelihoods and educational opportunities (Alobo, \& Obaji, 2016; Eme, Azuakor, \& Mba, 2018). The estimation was that close to five million people will be in urgent need of food assistance and about same number to be food insecure if not supported by the humanitarian community. This problem was as a result of the inability of displaced farmers to return to cultivate their land for the planting seasons. There is also the possible increase in susceptibility to disease due to the disruption in healthcare services, clean drinking water and sanitation (Mohammed, 2011; Amusan, \& Ejoke, 2017). Hence, the incidence of malaria and the likelihood of waterborne diseases to increase. The consequence of Boko Haram insurgence can be felt by the displaced people themselves, the local authorities and the communities that host them (UNICEF 2015; Alobo, \& Obaji, 2016; Amnesty International 2018). Besides, the people displaced experience loss of access to homes, lands, livelihoods, personal documentation, family members, and social networks which violate their human rights.

\section{Increasing Widows and Orphans}

Majority of residents who have the means flee their homes in Maiduguri, Yobe, Kano and other cities in the North-eastern part of Nigeria due to several attacks in form of shooting and bombing (Chukwurah, Okechukwu, \& Ogbeje, 2015). It is reported that more than 12,000 people have been killed in Boko Haram attacks across northern Nigeria and hundreds of thousands displaced (Meagher, 2014). A recent study by Eme et al., (2018) revealed that about 10,000 children were either killed or wounded between august 2003 and 2017. In corroboration, Amnesty International (2015) indicated that over 2000 among the injured children were permanently disabled. A lot of the children lost their parents or still have names of their fathers as missing due to the Boko Haram's attacks. It is noted that, over 1.4 million children have been displaced, most of whom cannot trace their parents which is a big challenge to take care of them since their number continues to grow beyond what can be contained if they are to be properly cared for (UNICEF 2015; Terwase, Abdul-Talib, Zengeni, \& Terwase, 2015). Studies have shown that experiences of violence by women and children are generally results in negative effects like aggression, violence, fear, sleep disorder, revenge seeking, depression, poor academic performance, panic and involvement in criminal activities as most of the husband and fathers are not alive to control and care for them (Amusan, \& Ejoke, 2017; Chinwokwu 
INTERNATIONAL JOURNAL OF ACADEMIC RESEARCH IN BUSINESS AND SOCIAL SCIENCES Vol. 9, No. 6, June, 2019, E-ISSN: 2222-6990 @ 2019 HRMARS

and Arop, 2014). Consequently, the abducted children majority of whom orphans are recruited as child soldiers and forced to involve in armed hostilities, participate in combats, spying, acting as decoys, and used as suicide bombers which expose them to psychological trauma (Amusan, \& Ejoke, 2017; HRW, 2014).

\section{Destruction of Property and Infrastructure}

The attacks and threat of boko haram has not changed despite the efforts of the security agencies and dialogue between the federal government and the representatives of this sect. While public buildings like police stations, government offices, prisons, schools and churches were burnt, about seven hundred lives of the sect members were reported to have perished (Nwankwo \& Falola 2009; Oyegbile \& Lawal 2009). Studies revealed that the dastardly insurgency of Boko Haram is clearly manifested in the various bombing and gun attacks on police stations, army barracks, prisons, churches, public institutions and prominent personalities ${ }^{5}$ (Agbiboa, \& Maiangwa, 2014; Matthew, \& Fada, 2014). For instance, the armed struggle between State Security forces and Boko Haram after an attack on a police station in northern state of Bauchi on 26 July 2009 which later spread to Yobe, Kano and Borno left about 800 dead (Alao, Atere, \& Alao, 2012). It is estimated that about 1400 schools were attached and destroyed through which over 2,000 teachers killed across Borno, Adamawa and Yobe in these three north-eastern states since Boko Haram insurgence in 2009 (UNICEF,2017; Eme et al., 2018). Besides, as indirect collapsing of school, hundreds of students have also been kidnapped which made many parents to stop their children from to school or making new enrolment. An example is the abduction of 276 schoolgirls from Chibok in Borno state in 2014 (Habila, 2017; Obasi \& Obe,2016; Eme et al., 2018; Aliyu, Moorthy, \& Idris, 2015; Onapajo \& Usman, 2015). The most recent one happened in Damaturu, Yobe state capital as insurgents invaded a school grounds and rounded up 113 school children in their pickup truck and sped off to the bush (ICG, 2018). These experiences affect the development of these people, especially the children as they might loss interest in schooling which relate to their expectations regarding their future life.

\section{High rate of unemployment and Poverty}

Studies view human security to include all the menaces that threaten human survival, daily life and dignity. Yobe State experienced security threats because of the activities of Boko Haram. The present insecurity in the state has been a source of worry for the people because it has affected the economic activities, movement of people, provision of goods and services (Abdullahi, \& Terhemba, 2014). Most violent conflicts in the country are not only linked to but also seen as causes of unemployment and poverty where majority of people find life unbearable due to difficulty in meeting the basic necessities like food, clothing, shelter and quality education. According to Obiyan and Usman, (2013), the Boko Haram crises are due to the inability of the federal and state governments to halt extreme poverty among the youth of Northern extraction. Ayegba, (2015) indicates that while unemployment reinforces poverty, violent conflict and extremist desirability is often times spurred by endemic and vicious poverty level. The majority of qualified youths wander without anything to do for a living as

\footnotetext{
5 See details in Ajayi, A. I. (1990). 'Boko Haram'and terrorism in Nigeria: Exploratory and
} explanatory notes. religion, 55, 65 . 
employment is not often based on merit but depends on how well connected an individual is with people in authority. The frequent bombing, killing and kidnapping of people including school children, burning of houses, schools and places of worship as well as sounds of gunshots scared the people causing insecurity among them. Thus leads to unemployment since most organizations and institution are forced to close down for the fear of attack which leads to worsen the already existing poverty situation in the area (Abdullahi, \& Terhemba, 2014). There is profound poverty and deprivation, inequality and disaffection between north and south of Nigeria. Poverty levels in the north-east and north-west are $40 \%$ higher than those in the south-west of the country, and unemployment is three times as high (Meagher, 2014). Meagher, (2014) indicates that young men with post-secondary qualifications are found working as tailors, load carriers and hawkers, while the poor and uneducated struggle to find even lowly informal work. The review discovered that the insurgence of Boko Haram has led to increasing rates of poverty and unemployment in the state. The World Bank Report in 2011 indicated that $54.7 \%$ of the nation's population lives in abject poverty due to the entrenched culture of endemic formal corruption (Uzodike \& Maiangwa, 2012).

\section{Psychological and Emotional Trauma}

Many people have been killed through bombing and guns by the attacks of the Boko Haram insurgents which has affected the people psychologically. The people, particularly women are at higher risk as reported by several studies that women and girls were being physically and sexually assaulted at most of the camps. This most often leads to unwanted pregnancies, illegal and unsafe abortions, maternal morbidity and mortality (Mohammed, 2011; Vu et al., 2014; Eme et al., 2018). Several studies found significant and long lasting negative consequences of conflict assaults to include physical injuries, sexually transmitted infections including HIV leading to psychological trauma (Mohammed, 2011; Adesina, 2013). These mental health problems are due to the pains through forced loss of personal values and positive affects so as to survive (Eme et al., 2018; Terwase et al., 2015). Eme et al. (2018) found that women and children who witness the kidnapping of parents and siblings, violence and death of their parents, husbands and family members developed psychological problems due to flashbacks. Studies showed that majority of the parents whose daughters were abducted by the Boko Haram could not bear the incidence died of heart attack after he watched the video that was released by the Boko Haram (Biodun 2014; Eme et al., 2018; Sahara Reporters, 2014). The victims of boko haram insurgency have gone through heart breaking in camps and Settlements, in host villages and towns (Alao, Atere, \& Alao, 2012).

\section{Discussion}

The success recorded on fight against the Boko Haram had motivated many Internally Displaced People IDP in the northeast, particularly, in Yobe state willing to return to their various communities. Ideally, there is the need for peace building and reconciliation in the northeast communities especially in Yobe state where the insurgency had cause serious negative impact on both socioeconomic and political spheres of life. It is a general belief that the socioeconomic breakdown has somehow made the country prone to violence creating mass poverty, inequality of opportunities, improper use of resources, revulsion of injustice, lack of educational opportunities, ignorance, corruption, and unemployment (Ale 2009; Adesoji, 2011). As indicated, the activities of Boko Haram 
INTERNATIONAL JOURNAL OF ACADEMIC RESEARCH IN BUSINESS AND SOCIAL SCIENCES Vol. 9, No. 6, June, 2019, E-ISSN: 2222-6990 @ 2019 HRMARS

lea to food scarcity in the long run. Besides, prices of food items and vegetables were very high as a result of the inability of traders to transport commodities due to general insecurity in the north. Therefore, the people in the northeast states often look to peace building as the only hope for a decent future for them (Alao, Atere, \& Alao, 2012). The scariest aspect of this sect is that its attack has no regard for any establishment including security, international agencies, press, private individuals, emirs, churches and mosques. Thus, nobody is safe and therefore the need for peaceful resolution through peace building.

Despite the return of peace in most areas, Boko Haram continued to carry out periodic attacks like suicide bombings, widespread sexual and gender based violence, kidnappings and forced recruitment, in the northeast. Boko Haram has become a significant security threat to the Yobe state through its indiscriminate attacks on civilians, security agencies, destruction of public and private properties, and kidnappings. Amusan \& Oyewole, 2015) Boko Haram operation in 2002 through its indiscriminate attacks was a significant security threat to Nigerians. The region is now suffering from poor social cohesion among its people due to the insurgency in the region. People who share the same faith, live and work together do not trust one another any longer. The atrocities committed against the innocent citizens by the Boko Haram armed group, their sponsors and sympathizers had negatively affected relations within and between families, religious groups and tribes in the state. The inequality, poverty, unemployment, corruption at all levels, perceived anti-Islamic stance of the state, the expansionist desires of Muslims, or a lack of regulation of Islamic teachings are issues that brought about Boko Hara insurgence (Amusan, \& Ejoke, 2017; Amusan \& Oyewole, 2014).

The overall effect of the identified negative effect of Boko Haram insurgency in Yobe communities had brought a huge agonies and humanitarian crises in the entire state communities and its neighbouring environs. Many villages have been razed down, infrastructure destroyed, including hundreds of home, school and business premises. These wanting destruction slowed down the national economic growth and development because most investors will not put their capital in a crisis ridden region which is clear as existing Multinational Companies relocate to safer territories due to infrastructural decay. This is said to worsen the unemployment and lead to youth restiveness, thereby making crime a profitable venture and attractive (Alao et al., 2012). The situation and thousands of citizens have been both internally and externally displaced. Most of the family bread winners were killed leaving behind a large number of widows and orphans. Studies including the Amnesty International Report (2017) indicated an estimated 2 million people have been internally displaced in northern Nigeria since the beginning of the insurgency. Of these 2 million, the majority live in host communities, while the remainder lives in Internally Displaced Persons (IDP) camps (Chibuike, \& Eme, 2019; Marchal, \& Salem, 2018). The crucial issue is that, most of the internal displaced are productive farmers and trades men by profession whose absence can affect services and food production in the country and worsen the problem of food importation.

The violence caused by Boko Haram has caused psychological trauma on its victims, society and the state at large. The insurgency had brought psychological and emotional trauma among the victims and people of the state. This explain why Farouk (2012) described Boko Haram is a source of nightmare to every male and female because many that have gone to search for their daily bread have never returned. Most people who survived the attacks live in a state of anxiety and fear of reoccurrence of further attacks. The exposure of the people to the serious traumatizing event like 
bomb blast, military combat, rape, conflict accidents or horrifying experiences seriously affect them since those events are beyond the normal occurrences in their everyday typical life. As a result, they experience recurrent, intrusive recollections and nightmares of the events in the minds of those who observers such traumatic events (Adesina, 2013). Therefore, they need psycho-social and emotional support, rehabilitation and resilience as well as reintegration process.

On allegations of human rights violations by the Nigerian security forces, there have recently been some indicators that the government are making effort to address the issue. Even though, some political leaders in the North have been accused as covert backers of Boko Haram even though there is no evidence to that thus not even ambivalence and empathy are sufficient grounds to establish collaboration or complicity ${ }^{6}$ (Adepoju, 2012). The government in March 2016 announced the creation of a Human Rights Desk for the Nigerian Army. The desk is comprised six lawyers from the Nigerian Bar Association and the representative of legal unit of the army. The new body will investigate allegations of human rights abuses perpetrated by soldiers. It will also work to strengthen the army's capacity to protect human rights and report annually on their progress (UNHRC, 2016).

\section{Relevance of the Study}

The study may contribute to the understanding of how sustainable livelihood strategies and economic development interventions help children and women in conflict ridden societies. It may contribute to the body of knowledge if students and academicians use it as a point of reference to conduct studies on how to improve the lives of people, particularly the victims of religious or inter and intra ethnic conflict. The study will also serve as a source of knowledge to complement the efforts of the government agencies in Nigeria in particular and the other countries that fight terrorism to improve the lives of people through sustainable implementation of developmental programs. Besides contributing to the advancement of knowledge on the impacts of Boko Haram insurgency, this research will provide a basis for policy making towards managing and resolving ethnic or religious conflicts. The result of the study may be beneficial mostly to policy makers who are responsible in the formulation and implementation of workable and feasible development programs and policies for women and children who are mostly the worse sufferers. It will also provide important information to development agencies aimed at improving the living standards of vulnerable groups in society. The study makes valuable policy recommendations on how to reposition the fight against terrorism in Nigeria in particular and world at large for better results. The findings may give fair and representative implications of conflict which may contribute to the national and global effort in ensuring security through sustainable conflict resolution.

\section{Conclusion}

The paper found that Boko Haram insurgency led to humanitarian crises as shown in human casualties, human right abuses, displacement of women and children and refugee debacle, livelihood crisis and public insecurity in the country. The study also revealed low level of primary school attendance under the crisis situation in the affected parts of the country. Besides, parents and

\footnotetext{
${ }^{6}$ Ajayi, A. I. (1990). ‘Boko Haram’and terrorism in Nigeria: Exploratory and explanatory notes. religion, 55, 65.
} 
teachers were unwilling to send their children back to the affected primary schools. The study revealed negligence on the part of the federal and state governments in ensuring better, effective and functional policies. Achieving peace and peace-building are the most difficult aspect of conflict management and resolution. The task of peace building goes beyond absence of violence or unrest but it goes further to achieve and restores the past glories in the relationship as if no conflict had taken place between the warring parties. This can only be achieved if there is political will to address the issues. For instance, lack of proactive security measures, peace approach to security and policies that equitably address poverty and unemployment were also found.

\section{Recommendations}

The following recommendations were made based on the findings:

- Collective efforts be geared towards Peace-building by all Nigerians. Peace-building should not be seen as a monopoly of Governments alone, but everybody should join hands /forces in eradicating the insurgency and intensify effort towards peace-building.

- The defense policy of the Nigeria should be overhauled so as to make both the police and the military proactive than being defensive.

- Economic and financial corruption need to be checkmated in order to ensure economic and infrastructural development that would eradicate poverty and unemployment among Nigerian youths.

- Army, police, state security service, non-state actors should be sensitizing and trained to fight against insurgency. Their activities should be monitored by the independent committee under the Presidency.

- Nigeria should not depend on her neighbours for help; rather efforts should be made to block the porous borders, which easily give access to foreigners.

- Twenty-four hours' surveillance should be mounted around the borders in order to avoid importation and indoctrination of alien ideology such as the Boko Haram.

- Dialogue on peace among different religious followers and ethnic groups be encouraged by governments, traditional and community leaders at all level.

- Human-right be observed, abuses and excessive use of force, corrupt and unprofessional practices be check mate and abusers of such be severely dealt with.

- The Nigerian state should desist from addressing the symptom instead of the cause. Consistent deployment of security personnel is only a first aid measure. The long-term solution is good governance with a robust institutional framework that ensures a prudent and effective management of resources to better the lot of its citizenry.

\section{References}

Abdullahi, U., \& Terhemba, G. A. (2014). Effects of insecurity on primary school attendance in Damaturu metropolis, Yobe State, Nigeria. Journal of Research in Education and Society, 5(1), 32-38.

Adepoju, O. (2012). "What is the Source of Boko Haram's Sophisticated Military and Propaganda Strategy" in yorubaafairs@googlegroups.com 
INTERNATIONAL JOURNAL OF ACADEMIC RESEARCH IN BUSINESS AND SOCIAL SCIENCES

Vol. 9, No. 6, June, 2019, E-ISSN: 2222-6990 @ 2019 HRMARS

Adesina, O. J. (2013). Predicting the Effect of Counselling on the Psychological Adjustment of Boko Haram Victims in Nigeria. AFRREV IJAH: An International Journal of Arts and Humanities, 2(4), 205-216.

Adesoji, A. (2010). The boko haram uprising and Islamic revivalism in Nigeria. Africa Spectrum, 45(2), 95-108.

Adesoji, A. O. (2011). Between Maitatsine and Boko Haram: Islamic fundamentalism and the response of the Nigerian state. Africa Today, 57(4), 99-119.

Adetoro, R. A. (2012). "Corruption in Nigeria"s democratic governance - the case of oil subsidy scandal". Being a paper presented at the 2nd National Conference of the Faculty of Social Science and Management, University of Education, Winneba, Ghana held between 13th 15th March, 2012.

Agbiboa, D., \& Maiangwa, B. (2014). Why Boko Haram kidnaps women and young girls in northeastern Nigeria. Conflict Trends, 2014(3), 51-56.

Alao, D. O., Atere, C. O., \& Alao, O. (2012). Boko-Haram insurgency in Nigeria: The challenges and lessons. Singaporean Journal of Business, Economics and Management Studies, 51(1106), 115.

Ale, A. (2009). Boko Haram: Soyinka Blames Government. Saturday Punch (Lagos), 15 August, p. 8.

Aliyu, A., Moorthy, R., \& Idris, N. A. B. (2015). Towards understanding the Boko Haram phenomenon in Nigeria. Asian Social Science, 11(10), 307.

Alobo, E., \& Obaji, S. (2016). Internal displacement in Nigeria and the case for human rights protection of displaced persons. JL Pol'y \& Globalization, 51, 26.

Amnesty International (2018). 'They betrayed us' women who Survived Boko Haram Raped, Starved \& Detained in Nigeria, London: Amnesty International.Amnesty International report (2017) Retrieved from : https://www.amnesty,org/en/countries/nigeria/report-nigeria89118.Access on 22/05/19

Amusan, L., \& Oyewole, S. (2015). Boko Haram: Between terrorism and counterterrorism. The Thinker, 64, 58-61.

Austin, J., Guy, S., Lee, Jones, L., McGinn, T., \& Schlecht, J. (2008). Reproductive health: A right for refugees and internally displaced persons. Reproductive Health Matters 16:10-21.

Ayegba, U. S. (2015). Unemployment and poverty as sources and consequence of insecurity in Nigeria: The Boko Haram insurgency revisited. African Journal of Political Science and International Relations, 9(3) 90-99.

Bakare, W., Ademola, A., \& Hamed, S. (2009). Islamic Militant leader killed-Borno Government. The Punch (lagos), 31 July, p. 5.

BBC (2015) "Nigeria Boko Haram: Militants 'technically defeated' - Buhari" Retrieved from http://www.bbc.com/news/world-africa-35173618 accessed on 12/03/19

Biodun, K., (2014) Chibok: Mother of Abducted Girl Dies. Retrieved from http://thenationonlineng.net/new/chibok-mother-abducted-girldies/,Accessed 19/12/2018.

Bumah, J, \& Abimbola, A. (2009). The Boko Haram Tragedy and Other Issues. The Punch (Lagos), 6 August, 40.

Chibuike, U. C., \& Eme, O. I. (2019). Terrorism \& its Socio-Economic Effects in Nigeria. Journal of Contemporary Research in Social Sciences, 1(1), 97-113. 
INTERNATIONAL JOURNAL OF ACADEMIC RESEARCH IN BUSINESS AND SOCIAL SCIENCES

Vol. 9, No. 6, June, 2019, E-ISSN: 2222-6990 @ 2019 HRMARS

Chinwokwu, E. C., \& Arop, S. K. (2014). Socio-psychological effects of political violence and war on gender in Nigeria. Mediterranean Journal of Social Sciences, 5(26), 44.

Chukwurah, D. C., Okechukwu, E., \& Ogbeje, E. N. (2015). Implication of Boko Haram terrorism on northern Nigeria. Mediterranean Journal of Social Sciences, 6(3), 371.

Eme, O. I., Azuakor, P. O., \& Mba, C. C. (2018). Boko Haram and Population Displacement in Nigeria. Practicum Psychologia, 8(1).

Eric, G. (2012). School attendance falls in northern Nigeria after Boko Haram attacks. International Education News.

Farouk, C. (2012). Who are Nigerian's Boko Haram Islamists -BBC News\| Retrieved from http://www.bbc.co.uk/news/world. African 13809501 Retrieved 2019-01-25.

Forest, J. J. (2012). Confronting the terrorism of Boko Haram in Nigeria (No. JSOU-12-5). Joint Special Operations Univ Macdill Afb Fl.

Habila, H. (2016). The Chibok Girls: Kidnappings and Islamist Militancy in Nigeria, Oxford: New York.

Human Right Watch (2014). Those terrible weeks in their camp: Boko Haram violence against women and girls in northern Nigeria. United Sates of America.

IDMC (2015). Nigeria IDP Figures Analysis2015. Retrieved from http://www. Internal displacement.org/sub-saharan-africa/nigeria/figures-analysis.

Licklider R. (1993). "The Consequences of Negotiated Settlements in Civil Wars, 1945-1993", American Political Science Review, 89:3 (September 1995), pp. 685-687.

Marchal, R., \& Salem, Z. O. A. (2018). What is the concept of "radicalization" good for? Politique africaine, (1), 5-20.

Matthew, A. A., \& Fada, A. A. (2014). Evaluating the impact of boko haram terrorism on yankari game reserve as a tourist resort in Bauchi State, Nigeria. IOSR Journal of Humanities and Social Science, 19(2), 57-61.

Meagher, K., \& Hassan, I. H. (2014). The informal economy and Islamic radicalization in northern Nigeria. Radicalization, Counter-Radicalization and Deradicalization in Northern Nigeria. Nigeria Security and Reconciliation Programme, Abuja.

Meagher, K. (2014). Beyond terror: addressing the Boko Haram challenge in Nigeria. Norwegian Peace Building Resource Center Policy Brief.

Mohammed, A. A. (2011). Familial and Economic Impacts of the Dagbon Chieftaincy Conflict: A Case Study of Married Women in Kanvilli, Tamale, Ghana (Unpublished Doctoral dissertation, Kulliyyah of Islamic Revealed Knowledge and Human Sciences, International Islamic University Malaysia

Nwankwo, C., \& Falola, F. (2009). Boko Haram: Another 140 Kids, Women Rescued, 780 Killed in Maiduguri Alone-Red Cross, Victims Given Mass Burial. The Punch, 3.

Obasi, N. I \& Obe, A. (2016). "The Chibok girls must be found - and freed", Crisis Group Commentary, $8(1)$.

Obiyan, A. S., \& Usman, S. A. (2013). Terrorism in Nigeria and Its Implications for National Integration, Development and Security. Lapai Int. J. Polit.(LIJOPOL), 1(2).

Onapajo, H., \& Usman, A. A. (2015). Fueling the flames: Boko Haram and deteriorating ChristianMuslim relations in Nigeria. Journal of Muslim Minority Affairs, 35(1), 106-122. 
INTERNATIONAL JOURNAL OF ACADEMIC RESEARCH IN BUSINESS AND SOCIAL SCIENCES

Vol. 9, No. 6, June, 2019, E-ISSN: 2222-6990 (C) 2019 HRMARS

Onuoha, F. C. (2011). Countering the financing of Boko Haram extremism in Nigeria. Journal for the Prevention and Combating of Terrorism, 2(1), 89-118.

Owuamanam, J., Falola, F., \& Hamed, S. (2009). The rise, threat and fall of Boko Haram. Saturday Punch, 1, 2-3.

Oyegbile, O., \& Lawal, A. (2009). Shielding Patrons of Boko Haram. Tell (Lagos), 17, 67-71.

Terwase, I. T., Abdul-Talib, A. N., Zengeni, K. T., \& Terwase, J. M. (2015). The psychological trauma on Boko Haram victims in Nigeria: Conflict resolution perspective. Mediterranean Journal of Social Sciences, 6(6 S4), 519.

UNHCR (2016) "UNHCR chief launches U\$241 million appeal for conflict-displaced people in Lake Chad Basin region Africa", Published 16 December 2016. Retrieved from : http://www.unhcr.org/news/press/2016/12/5853ccb64/unhcr-chief-launches-u241-millionappeal-conflict-displaced-lake-chad-basin.html

UNHRC (2016) Nigeria creates a military Human Rights Desk. Retrieved From:http://www.ohchr.org/EN/NewsEvents/Pages/NigeriacreatesamilitaryHumanRightsDe sk.aspx_Francis, A paper presented during a security session entitled "Tortuous Path to Peace: The Lome Accord and Postwar Peacebuilding in Sierra Leone" 31:3 (September 2000), p. 357.

UNICEF (2015). Boko Haram Displaced Children Now over 1.4 Million, Retrieved from http://leadership.ng/news/461825/boko-haram-displaced-children-now-over-1-4-millionunicef, Accessed 19/12/2018.

Uzodike, U. O., \& Maiangwa, B. (2012). Boko Haram terrorism in Nigeria: Causal factors and central problematic. African Renaissance, 9(1), 91-118.

Walker, A. (2012). What is Boko Haram? (Vol. 17). Washington, DC: US Institute of Peace.

\section{Corresponding Author:}

Md Sayed Uddin

Email: sayed@ums.edu.my 